\title{
Tissue localization of threonine oxidation in pigs
}

\author{
BY NATHALIE LE FLOC'H, JEAN-NOËL THIBAULT AND BERNARD SÈVE \\ Station de Recherches Porcines, INRA 35590 Saint Gilles, France
}

(Received 22 April 1996 - Revised 24 June 1996 - Accepted 1 August 1996)

\begin{abstract}
Two experiments were designed to determine the tissue distribution of threonine oxidation through the threonine dehydrogenase (EC 1.1.1.103) pathway in pigs. The first experiment was conducted on eleven Piétrain $\times$ Large White piglets. The piglets were slaughtered at 5,12 or $20 \mathrm{~kg}$ after $1 \mathrm{~h}$ of infusion with $\mathrm{L}-\left[\mathrm{U}-{ }^{14} \mathrm{C}\right]$ threonine $(55 \mathrm{kBq} / \mathrm{kg})$ mixed with unlabelled threonine $(100 \mathrm{mg} / \mathrm{kg})$. In the second experiment, four Piétrain $\times$ Large White and four Large White piglets (10 kg body weight) were infused with $\mathrm{L}-\left[1-{ }^{13} \mathrm{C}\right]$ threonine $(50 \mathrm{mg} / \mathrm{kg}$ ) mixed with $50 \mathrm{mg} / \mathrm{kg}$ unlabelled threonine for $1 \mathrm{~h}$, then killed for tissue sampling. In the two experiments, threonine dehydrogenase specific activity and threonine and glycine specific radioactivities and enrichments were measured in several tissues and in plasma. The higher level of labelling of threonine in the pancreas than in the liver suggested either a lower protein degradation rate or a faster rate of threonine transport in the liver than in the pancreas. Threonine dehydrogenase activity was found only in the liver and the pancreas. Whereas liver and pancreas threonine dehydrogenase specific activities were similar, glycine specific radioactivity and enrichment were 12- to 14-fold higher in the pancreas than in the liver. This is probably the consequence of a higher production rate of glycine from sources other than threonine (protein degradation, de novo synthesis from serine) in the liver than in the pancreas. Our results showed that Large White pigs could oxidize more threonine than Piétrain $\times$ Large White pigs. This could be related to the difference in growth performance and dietary $N$ efficiency for protein deposition between these two genotypes.
\end{abstract}

Threonine: Amino acids: Genotype: Pigs

Threonine is often a limiting amino acid for growth and maintenance in diets consumed by pigs. Consequently, conservation of threonine from oxidation is crucial to maintain protein synthesis and deposition. In pigs, threonine dehydrogenase (EC 1.1.1.103; TDG) is the main enzyme involved in threonine degradation (Ballèvre et al. 1990; Le Floc'h et al. 1995). This enzyme catalyses the oxidation of L-threonine to 2-amino-3-oxobutyric acid which is spontaneously decarboxylated to give aminoacetone (Green \& Eliott, 1964) or glycine and acetyl CoA when TDG is coupled with 2-amino-3-oxobutyrate CoA ligase (EC 2.3.1.29) (Tressel et al. 1986). In vivo the production of glycine is predominant (Bird et al. 1984), but the measurement of aminoacetone production is used for in vitro TDG specific activity determination (Hartshorne \& Greenberg, 1964). However, in vitro enzyme activity does not always reflect in vivo oxidation since it does not integrate certain regulatory processes such as transport into the cell or inter-organ flux. It is possible to determine in vivo threonine oxidation through the infusion of labelled threonine and measurement of labelled $\mathrm{CO}_{2}$ (Kang-Lee \& Harper, 1978) but the measurement of glycine (Ballèvre et al. 1990) production rate is the preferred approach.

The main problems with this latter technique are the compartmentation of amino acid metabolism and the difficulty in determining the true amino acid precursor pool for oxidation. When the plasma was chosen as the precursor pool, this led to an erroneous 
estimation of the absolute value of oxidation since, in pigs, threonine oxidation occurs mainly in the liver (Ballèvre et al. 1990). However, we have shown in a previous experiment that threonine oxidation to glycine also takes place in other tissues (Le Floc'h et al. 1995) and that the contribution of the liver to total threonine oxidation decreases with the level of dietary threonine as a consequence of a reduced threonine transport into the liver (Le Floc'h et al. 1996). It is necessary to determine which tissues are involved in this degradative pathway in order to improve the model used to estimate the true rate of in vivo threonine oxidation to glycine and to determine the partition of oxidation between the liver and the extra-hepatic tissue(s) according to the level of dietary threonine supply.

In the present paper we report the results of two experiments in which we have measured and compared, in different tissues, the TDG activity and glycine enrichment or specific radioactivity after the infusion of labelled threonine. Moreover, we have compared threonine oxidation levels in two genotypes of pigs which are known to present different growth performances and responses to nutrient supply.

\section{MATERIALS AND METHODS}

\section{Chemicals}

L-[U- $\left.-{ }^{14} \mathrm{C}\right]$ Threonine $(6.7 \mathrm{GBq} / \mathrm{mmol})$ was provided by ICN France (Orsay, France) and L$\left[1-{ }^{13} \mathrm{C}\right]$ threonine by Isotec France (Saint Quentin, France). All other chemicals, except aminoacetone (synthesized in our laboratory), were purchased from Sigma (St Louis, MO, USA) or Boehringer (Mannheim, Germany).

\section{Animals and infusion protocol}

Expt 1. Twelve female Piétrain $\times$ Large White pigs from the Institut National de la Recherche Agronomique (INRA) herd were used in this experiment. These pigs were selected in order to weigh approximately $5(4.39$, SE 0.11$), 12(11 \cdot 77, \mathrm{SE} 0.18)$ or $20(20.44$, $\mathrm{SE} 0.65) \mathrm{kg}$ at the time of the infusions. A catheter was inserted under anaesthesia through each pig's jugular vein into the cranial vena cava as previously described (Le Floc'h et al. 1995). The animals were fed twice daily (Table 1) and, in order to ensure a correct and constant nutritional status (Cortamira et al. 1991), piglets weighing $5 \mathrm{~kg}$ were fed on a liquid diet through a gastric tube. The dry diet was mixed with water $(1: 3, \mathrm{w} / \mathrm{w})$ and was delivered in liquid form with a syringe. A solution of threonine $(100 \mathrm{mg} / \mathrm{kg}$ body weight $(\mathrm{BW}))$ combined with $\mathrm{L}-\left[\mathrm{U}-{ }^{14} \mathrm{C}\right]$ threonine $(55 \mathrm{kBq} / \mathrm{kg} \mathrm{BW})$ was prepared in sterile saline $(9 \mathrm{~g} \mathrm{NaCl} / \mathrm{l})$ and passed through a $0.22 \mu \mathrm{m}$ filter before use. At $2 \mathrm{~d}$ after surgical preparation, this solution was infused via the jugular catheter for $1 \mathrm{~h}$ from $30 \mathrm{~min}$ after the meal. Blood $(20 \mathrm{ml})$ was sampled from the catheter and the piglets were killed with a lethal dose of pentobarbital. Liver, pancreas, kidney, spleen, lung, duodenum, heart and muscle were sampled and frozen in liquid $\mathrm{N}_{2}$ and stored at $-80^{\circ}$.

Expt 2. Four pairs of female littermate Piétrain $\times$ Large White and Large White pigs were selected at an average weight of $10 \mathrm{~kg}$. They were surgically prepared as described earlier. The infusion protocol was similar to the protocol of the first experiment (infusion of $100 \mathrm{mg}$ L-threonine/kg BW) except that L-[U- $\left.{ }^{14} \mathrm{C}\right]$ threonine was replaced by $\mathrm{L}\left[1-{ }^{13} \mathrm{C}\right]$ threonine $(50 \mathrm{mg} / \mathrm{kg} \mathrm{BW})$. Only one pig of each pair was infused and the other one was slaughtered at the same time in order to determine threonine and glycine basal ${ }^{13} \mathrm{C}$ abundance in the different tissues. 
Table 1. Composition of the diets $(\mathrm{g} / \mathrm{kg})$

\begin{tabular}{lcc}
\hline Ingredients & Weaner phase 1* $^{*}$ & Weaner phase 2* \\
\hline Barley & 414 & 145 \\
Wheat & - & 233 \\
Maize & - & 280 \\
Soyabean meal, 50 & 200 & - \\
Soyabean meal, 48 & - & 255 \\
Sweet dehydrated whey & 200 & - \\
Skimmed milk powder & 80 & 50 \\
Fish meal & 50 & - \\
Tallow & 20 & 18 \\
Dicalcium phosphate & 18 & $\mathbf{1 0}$ \\
Limestone & 11 & $\mathbf{4}$ \\
lodized salt & - & - \\
L-Threonine & $\mathbf{0 \cdot 8}$ & - \\
DL-Methionine & $\mathbf{1 . 2}$ & 5 \\
Trace mineral and vitamin premix $\dagger$ & $\mathbf{5}$ & \\
\hline
\end{tabular}

* Weaner phase 1 was offered to $5 \mathrm{~kg}$ piglets and weaner phase 2 to 12 and $20 \mathrm{~kg}$ piglets.

$\dagger$ For details of premix see Le Floc'h et al. (1996).

In the two experiments, the amount of infused threonine corresponded to approximately one quarter of ingested threonine per day. Unlabelled threonine was included in the infusion of labelled threonine in order to (1) reduce the difference in the precursor pool (threonine) labelling in different tissues and (2) increase glycine production from threonine and, consequently, to improve the detection of TDG in tissues where threonine oxidation is low.

\section{Analytical procedure}

Tissue samples $(10 \mathrm{~g})$ and plasma $(20 \mathrm{ml})$ were homogenized in $40 \mathrm{ml} \mathrm{TCA}(100 \mathrm{~g} / \mathrm{l})$ and centrifuged for $20 \mathrm{~min}$ at $133 \mathrm{~g}$. Amino acids from the supernatant fraction were then purified through cation exchange resin (AG 40W-X8, 100-200 mesh, Biorad, Ivry Sur Seine, France) and eluted with $4 \mathrm{M}-\mathrm{NH}_{4} \mathrm{OH}$. $\mathrm{NH}_{3}$ was evaporated under vacuum and amino acids were recovered in a small volume $(1 \mathrm{ml})$ of sodium acetate buffer $\mathrm{pH} 2 \cdot 2$, for liquid chromatography, or in water, for mass spectrometry analysis.

Approximately half the tissue amino acids sample and $75 \%$ of plasma amino acids were saved for glycine and threonine specific radioactivities measurement. Glycine and threonine were purified by liquid chromatography (Multichrom amino acid analyser, Beckman, München, Germany). Separation was performed on cation exchange resin (CK 10S, Mitsubichi; Prolabo, Gradignan, France) with a $10 \times 400 \mathrm{~mm}$ column. Amino acids were eluted (flow rate $57 \mathrm{ml} / \mathrm{h}, 57^{\circ}$ ) with sodium citrate buffer (pH 2.92, $70 \mathrm{~g} / \mathrm{l}$ and $120 \mathrm{~g} / \mathrm{l}$ isopropanol for glycine and threonine respectively) and collected with an automatic fraction collector (Gilson 202, Villiers Le Bel, France). Under these conditions the retention times are approximately $75 \mathrm{~min}$ and $130 \mathrm{~min}$ for threonine and glycine respectively. There was no detectable radioactivity in serine, alanine or asparagine which could have contaminated the threonine and glycine fractions. Glycine and threonine concentrations in the eluate were determined by liquid chromatography and ninhydrin colouration. Radioactivity of the pooled fractions was measured by liquid scintillation counting (Ultima gold or Hionic Fluor, Packard, Downers Grove, IL, USA) on a liquid scintillation analyser (Tri-Carb 1300 TR, Packard). 
Threonine enrichment was determined by GC-mass spectrometry (GC-MS) in electron impact ionization mode (GC 8060 chromatograph coupled to a VG Platform II, Fisons Instruments, Altrincham, Ches.) after derivatization of the sample with N-methyl$\mathrm{N}$-tert-butyldimethylsilyl trifluoroacetamide (MTBSTFA). Amino acid derivatives were separated on a $30 \mathrm{~m}, 0.25 \mathrm{~mm}$ inner diameter (i.d.) and $0.1 \mu \mathrm{m}$ film thickness capillary column (DB 5-MS, J\&W Scientific, Courtaboeuf, France). He gas was used as a carrier (flow $1.2 \mathrm{ml} / \mathrm{min}$ ). Best chromatographic resolution of the amino acid derivatives was observed using a temperature programme which started at $100^{\circ}(2 \mathrm{~min})$, rose at the rate of $10^{\circ} / \mathrm{min}$ to $250^{\circ}$ and was kept constant for $6 \mathrm{~min}$. Selected ion monitoring mode (SIM) was used to scan

the specific ions masses (M-57) and (M-57) +1 for tri-tert-butyl dimethylsilyl threonine $(\mathrm{m} / \mathrm{z}=404$ and 405 respectively). The peak areas ratios $(405: 404)$ were calculated for each tissue in the infused pig $\left(R_{\text {enriched }}\right)$ and the control pig $\left(R_{0}\right)$. Threonine enrichment was calculated with the conventional formula:

$$
\text { enrichment }(A P E, \%)=100 \times\left(R_{\text {enriched }}-R_{0}\right) /\left[1+\left(R_{\text {enriched }}-R_{0}\right)\right] \text {. }
$$

Due to its lower enrichment, ${ }^{13} \mathrm{C}$ content of glycine was determined by $\mathrm{GC}$-combustionisotope ratio mass spectrometry (GC-C-IRMS) (GC 8130 chromotograph interfaced with a VG Isochrom mass spectrometer, Fisons Instruments) after derivatization with ethyl chloroformate according to the method described by Husek (1991). Separation of amino acid derivatives was performed on a DB 1701 capillary column (J\&W Scientific) with the following characteristics: $30 \mathrm{~m}, 0.25 \mathrm{~mm}$ i.d. and $0.25 \mu \mathrm{m}$ film thickness. In this study, the best chromatographic conditions were as follows: injector temperature was $240^{\circ}$, the column was held isothermal at $120^{\circ}$ for 4 min after injection, then the temperature was increased to $190^{\circ}$ at the rate of $20^{\circ} / \mathrm{min}$, maintained constant for $4 \mathrm{~min}$, and further elevated at the rate of $30^{\circ} / \mathrm{min}$ to $250^{\circ}$ which was held for $4 \mathrm{~min}$.

TDG specific activity was measured as the rate of aminoacetone formation in vitro, as previously described (Le Floc'h et al. 1994).

\section{Statistical analysis}

Data were submitted to ANOVA according to the general linear models (GLM) procedure of the Statistical Analysis System (1989). The effects of weight and genotype were tested against the residual variation between pigs. Tissues and plasma values were compared against the residual variation within animal. When a statistical difference was established by Fisher-Snedecor $(P<0.05)$, means were compared by Student's $t$ test and declared different at $P<0.05$.

\section{RESULTS}

\section{Threonine dehydrogenase specific activity}

TDG activity was found in pancreas and in liver but not in the other tissues. In pigs infused with L-[U- $\left.{ }^{14} \mathrm{C}\right]$ threonine (Fig. 1(a); Expt 1), liver TDG specific activity was not affected by the weight of pigs whereas pancreas TDG activity was higher in $20 \mathrm{~kg}$ pigs than in $12 \mathrm{~kg}$ pigs. Enzyme specific activity was significantly higher in the liver than in the pancreas in $10 \mathrm{~kg}$ pigs $(P=0.02)$ whereas the reverse was true in $20 \mathrm{~kg}$ pigs $(P<0.01)$. Results of the second experiment (Fig 1(b)) showed that liver TDG specific activity was similar in Large White and Piétrain $\times$ Large White pigs whereas pancrease TDG activity was significantly higher in Large White than in Piétrain $\times$ Large White pigs $(P<0.01)$. 

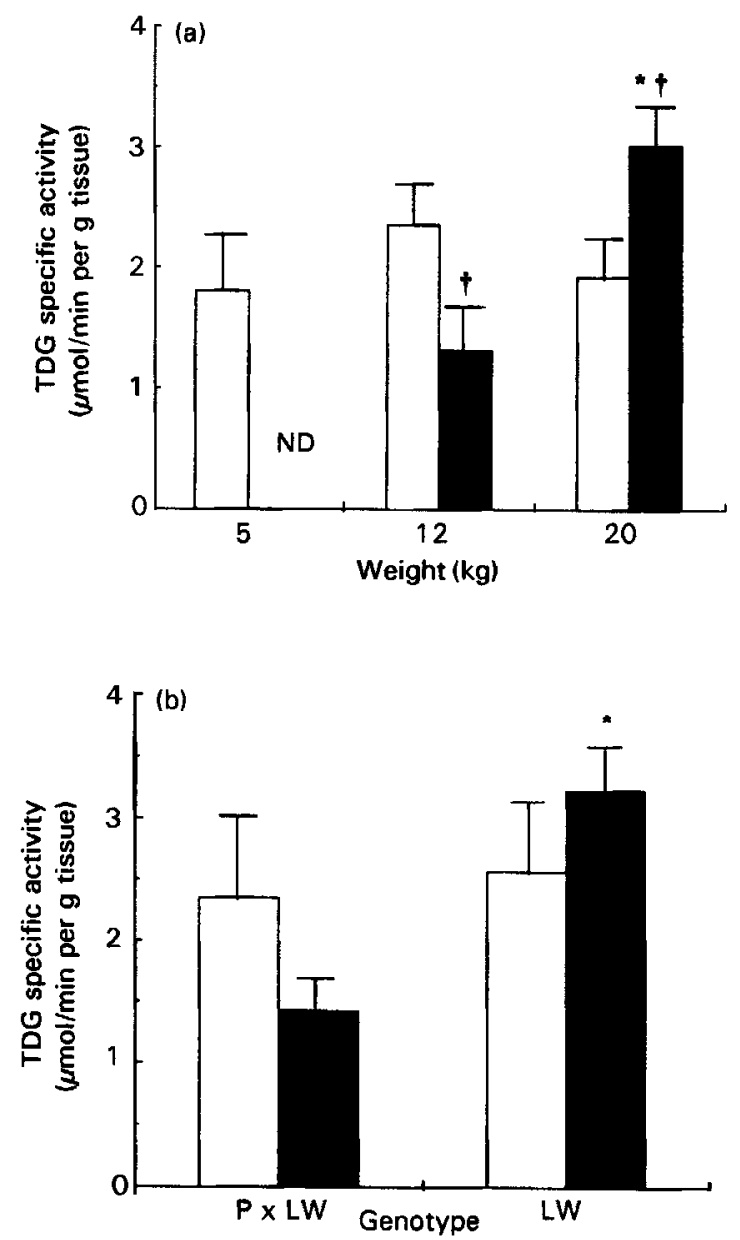

Fig. 1. Liver ( $\square$ ) and pancreas ( $\square$ ) L-threonine dehydrogenase (TDG) specific activity, expressed as the rate of aminoacetone formation, in pigs infused with (a) $\mathrm{L}-\left[\mathrm{U}-{ }^{14} \mathrm{C}\right]$ threonine or (b) $\mathrm{L}-\left[1-{ }^{13} \mathrm{C}\right]$ threonine. Values are means for each group with their standard errors represented by vertical bars. Panel (a): $n 4$ for 5 and $20 \mathrm{~kg}$ live weight pigs and $n 3$ for $12 \mathrm{~kg}$ live weight pigs; panel (b): $n$ 4. Panel (a): * mean values were significantly different between stages of growth, $P<0.05$; $\uparrow$ mean value was significantly different from that for the liver, $P<0.05$. Panel (b): ${ }^{*}$ mean value was significantly different from that for $\mathrm{P} \times \mathrm{LW}$ pigs, $P<0.05$. ND, not determined; LW, Large White; $\mathrm{P}$, Piétrain.

\section{Threonine enrichment and specific radioactivity}

The values of threonine specific radioactivity and enrichment are presented in Table 2 . The results obtained with both tracers were similar. Because there was no effect of age or of genotype on threonine enrichment and specific radioactivity, the results are presented as means for each tissue. Threonine specific radioactivity was significantly higher in the pancreas than in the other tissues $(P<0.02)$. In pigs infused with L- $\left[1-{ }^{13} \mathrm{C}\right]$ threonine, threonine enrichment was significantly higher in the pancreas than in the liver and the heart $(P<0.05)$ and was close to plasma, kidney and muscle enrichments. Threonine enrichment measured in brain was much lower than in the other tissues $(P=0.0001)$. 
Table 2. Threonine enrichments (E) and specific radioactivities $(S R)$ in tissues and plasma of pigs after the infusion of $L-\left[1-{ }^{13} \mathrm{C}\right]$ threonine or $L-\left[U-{ }^{14} \mathrm{C}\right]$ threonine $\dagger$

(Mean values with their standard errors for eight (enrichment) or twelve (specific radioactivity) piglets)

\begin{tabular}{|c|c|c|c|c|}
\hline \multirow{2}{*}{$\begin{array}{l}\text { Infusion... } \\
\text { Tissue }\end{array}$} & \multicolumn{2}{|c|}{$\begin{array}{c}\mathrm{L}-\left[1-{ }^{13} \mathrm{C}\right] \text { Threonine } \\
\text { E (APE) }\end{array}$} & \multicolumn{2}{|c|}{$\begin{array}{c}\mathrm{L}-\left[\mathrm{U}-{ }^{14} \mathrm{C}\right] \mathrm{Threonine} \\
\text { SR }(\mathrm{Bq} / \mu \mathrm{mol})\end{array}$} \\
\hline & Mean & $S E$ & Mean & $\mathrm{SE}$ \\
\hline Liver & $20 \cdot 1^{*}$ & 1.0 & $33.9^{*}$ & $1 \cdot 1$ \\
\hline Pancreas & $22 \cdot 2$ & 0.7 & 40.9 & $1 \cdot 2$ \\
\hline Lung & $20 \cdot 4$ & 0.8 & $33.9 *$ & 1.0 \\
\hline Kidney & 21.8 & 0.7 & $35 \cdot 5^{*}$ & 0.9 \\
\hline Spleen & 20.6 & 0.6 & $35 \cdot 5^{*}$ & 0.8 \\
\hline Heart & $19 \cdot 4^{*}$ & 0.75 & $31 \cdot 1 *$ & 1.5 \\
\hline Brain & $10 \cdot 5^{*}$ & 0.9 & ND & \\
\hline Duodenum & $21 \cdot 1$ & 0.9 & $35 \cdot 5^{*}$ & 1.7 \\
\hline Muscle & $22 \cdot 1$ & 0.8 & $35 \cdot 8^{*}$ & $1 \cdot 5$ \\
\hline Plasma & 22.5 & 0.6 & $41 \cdot 2$ & 1.0 \\
\hline
\end{tabular}

APE, atom percent excess; ND, not determined.

* Mean values were significantly different from plasma value $(P<0.05)$.

$\dagger$ For details of procedures, see pp. 594-596.

\section{Glycine enrichment and specific radioactivity}

In all tissues, except in the liver and in the pancreas, glycine labelling was not different from plasma values. Glycine enrichment and specific radioactivity were significantly higher in the liver and in the pancreas than in the other tissues and in the plasma $(P=0.0001)$. Glycine specific radioactivity and enrichment were 12 - to 14 -fold higher in the pancreas than in the liver (Figs. 2(a) and 2(b)). Pancreatic and liver glycine specific radioactivities were significantly affected by the weight of pigs. In Expt 2, glycine enrichment in the pancreas was significantly lower $(P=0.001)$ in Piétrain $\times$ Large White than in Large White pigs but the same difference was not significant in the liver or in the plasma $(P=0.7)$. However, if the pancreas was excluded from the statistical analysis due to the higher variance, the difference between breed appeared to be significant in the liver and the plasma $(P<0.05)$.

\section{DISCUSSION}

The aim of the present study was to determine the tissue localization of threonine oxidation in the pig using simultaneously an in vitro (measurement of TDG specific activity) and an in vivo (infusion of labelled threonine) approach. The second approach was not quantitative but was presumed to be more sensitive for the detection of TDG activity. We assumed that a tissue could oxidize threonine if TDG activity was detected in vitro and if glycine enrichment or specific radioactivity was higher in this tissue than in the plasma during labelled threonine infusion. Our purpose was to reduce differences in intracellular oxidation precursor pool (threonine) labelling in order to limit variations of glycine labelling associated with the experimental procedure. The infusion technique was intermediate between the flooding-dose and the continuous-infusion techniques and it is important to point out that the results obtained with this technique were only qualitative because threonine oxidation rate based on steady-state equations could not be used in this 


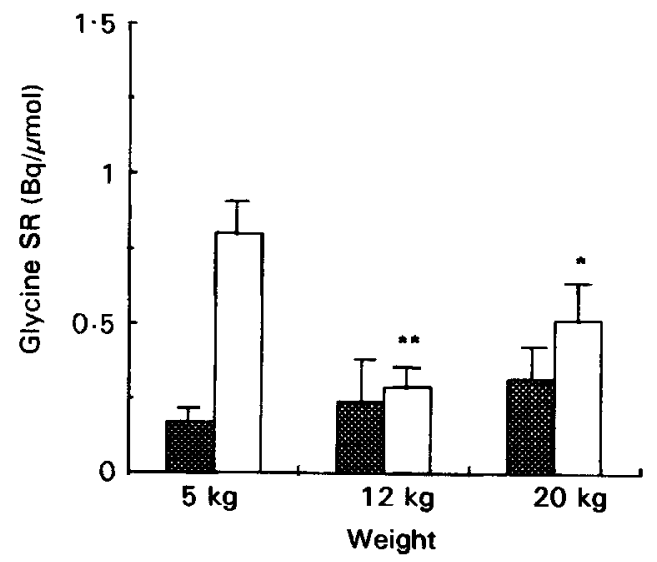

(a)

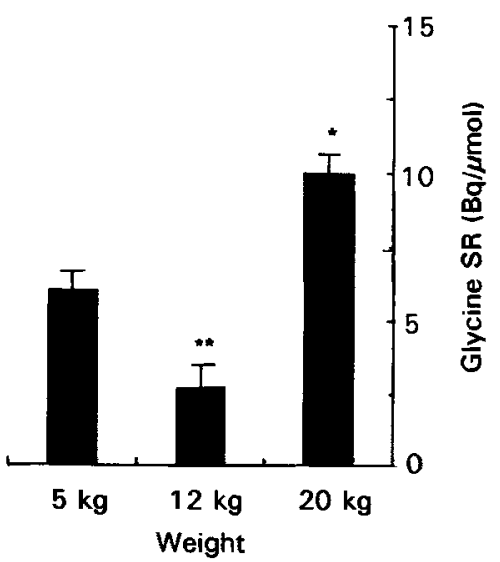

(b)
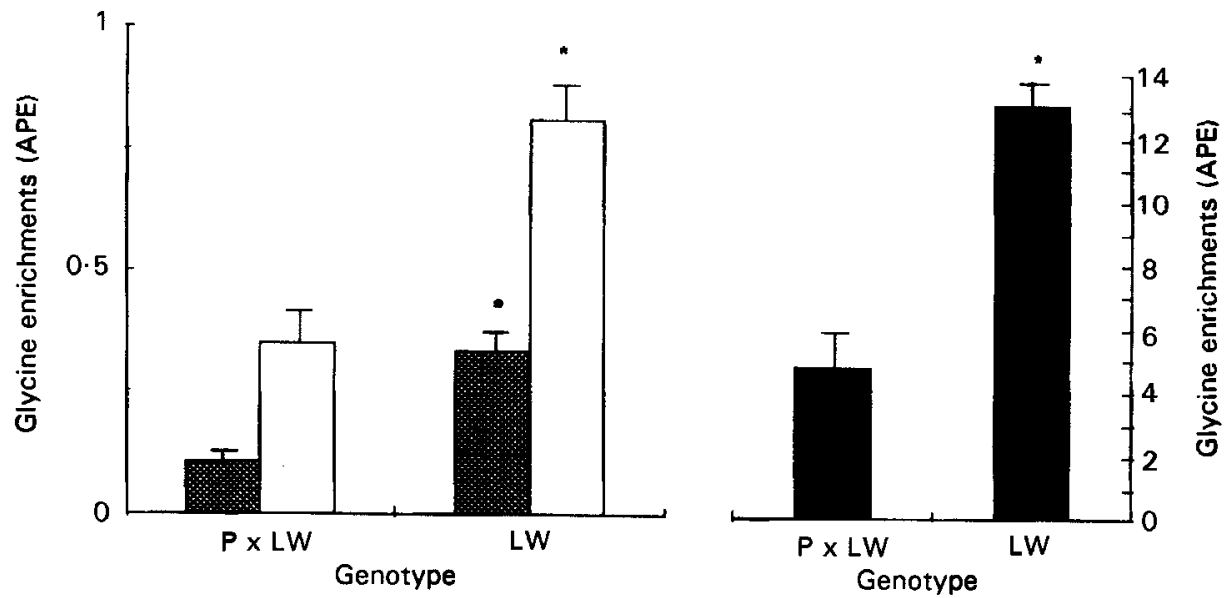

Fig. 2. Glycine (a) specific radioactivity (SR) and (b) enrichment measured in the plasma (圆), the liver ( $\square$ ) and the pancreas (D) of pigs infused with (a) $\mathrm{L}-\left[\mathrm{U}-{ }^{14} \mathrm{C}\right]$ threonine or $(\mathrm{b}) \mathrm{L}-\left[1{ }^{13} \mathrm{C}\right]$ threonine. Values are means for each group, with their standard errors represented by vertical bars. Panel (a): $\boldsymbol{n} 4$ for 5 and $20 \mathrm{~kg}$ live weight pigs and $\boldsymbol{n} \mathbf{3}$ for $12 \mathrm{~kg}$ live weight pigs; panel (b): $n$ 4. Panel (a): mean values were significantly different from those for $5 \mathrm{~kg}$ pigs: $* P<0.05$, ${ }^{* *} P<0.01$. Panel (b): * mean values were significantly different from those for $\mathrm{P} \times \mathrm{LW}$ pigs, $P<0.05$. APE, atom percent excess; LW, Large White; P, Piétrain.

experiment. Continuous infusion for $1 \mathrm{~h}$ was preferred to a bolus injection of threonine in order to avoid a large loss of tracer in the urine. Simultaneous infusion of labelled and unlabelled threonine, partly flooding the free pools, helped to minimize the consequence of protein degradation on intracellular threonine labelling and, since pigs were in an absorptive state as in our previous experiments (Le Floc'h et al. 1995, 1996), the effect of the dilution with dietary threonine in the liver and in the intestine. An associated advantage of unlabelled threonine infusion was to increase glycine production in tissues where the contribution of threonine oxidation to glycine flux is low. Since TDG activity was not induced by an excess of threonine (Le Floc'h et al. 1996), the infusion of unlabelled threonine probably had no effect on qualitative estimation and comparison of oxidative potential between pigs. 


\section{Compartmentation of threonine metabolism}

Intracellular amino acid enrichment depends both on the rate of exchange between plasma and tissue and on the dilution of labelled amino acids by unlabelled amino acids released by protein degradation. As discussed earlier, the infusion of unlabelled threonine should have reduce the difference in threonine labelling between tissues. Indeed, the results presented in Table 2 show that threonine enrichments and specific radioactivities were similar in the different tissues with two exceptions: the pancreas and the brain.

After $1 \mathrm{~h}$ of $\mathrm{L}-\left[\mathrm{U}-{ }^{14} \mathrm{C}\right]$ or $\left[1-{ }^{13} \mathrm{C}\right]$ threonine infusion the enrichment and specific radioactivity of free threonine in the pancreas were significantly higher than in the liver and close to the plasma value as previously noticed after $10 \mathrm{~h}$ of infusion (Le Floc'h et al. 1995). This result was unexpected since the turnover rate of pancreatic proteins is very fast compared with that of muscle (Simon et al. 1982; Ponter et al. 1994) and might have been expected to induce a lower pancreatic threonine enrichment. However, even after $6 \mathrm{~h}$ of $\mathrm{L}$ $\left[1-{ }^{14} \mathrm{C}\right]$ lysine or $\mathrm{L}-\left[1-{ }^{14} \mathrm{C}\right]$ leucine infusion, free lysine and leucine specific radioactivities measured in the pancreas of fasted pigs were higher than those of liver and close to the values measured in the other tissues (Simon et al. 1978, 1982). In this last case the low values of liver free lysine and leucine specific radioactivities were interpreted as the consequence of an increase in liver protein breakdown during fasting (Garlick et al. 1973), but this could not be so in our experiment where pigs were in an absorptive state. It was equally improbable that the high value of pancreatic threonine enrichment observed in the present experiment was due to tracer recycling as the infusion was for only $1 \mathrm{~h}$.

According to Simon et al. (1983), and more recently to Leterme et al. (1993), free amino acid labelling in the pancreatic juice is close to that of plasma and blood during a continuous tracer infusion. In the rat infused with $\left[{ }^{3} \mathrm{H}\right]$ leucine, Girard-Globa et al. (1980) showed that labelling of the precursor pool for pancreatic juice protein synthesis was close to that in plasma free amino acids. This is consistent with the fact that, during the infusion of labelled threonine, intra-tissue pancreas free threonine enrichment tended to equilibrate with plasma enrichment in the present as in previous experiments (Le Floc'h et al. 1995, 1996). Pancreatic juice protein synthesis is probably a major component of total protein synthesis activity in the pancreas. About $18 \mathrm{~g}$ protein is excreted daily by the pancreas of a $45 \mathrm{~kg}$ live weight pig (Corring, 1975). Consequently, amino acids entering the pancreas are little diluted since pancreatic juice protein degradation occurs in the intestine and recycling may occur in any tissues other than in the pancreas. Alternatively, threonine transport into the pancreas might be easier and faster than in the other tissues and particularly than in the liver. Conversely, the low value of threonine enrichment measured in the brain could be the consequence of the slow transport of threonine across the blood-brain barrier which prevents the negative effect of amino acid accumulation in the brain on food intake (Peng et al. 1973).

\section{Tissue localization of threonine oxidation}

Measurements of in vitro TDG specific activity in different tissues have shown that the enzyme is present in the liver and in the pancreas. No activity could be detected in the other tissues. This result was confirmed in vivo with the measurement of higher glycine enrichment and specific radioactivity in these tissues than in the plasma after the infusion of labelled threonine. It was in agreement with the data of previous experiments (Le Floc'h et al. 1995, 1996). The role of the pancreas in threonine metabolism has been described in the chicken by Davis \& Austic (1982). In this species, TDG specific activity is fivefold 
higher in the pancreas than in the liver. More recently, the same authors (Davis \& Austic, 1994) showed that the enzyme was widespread in many tissues. In rats, TDG specific activities measured in the brain and in the kidney represented 10 and $30 \%$ of liver activity when expressed per gram of tissue (Green \& Eliott, 1964), but, taking into account the mass of the liver, $87 \%$ of TDG activity appeared to be located in the liver. In our experiment, although in vitro TDG specific activities were similar in the liver and in the pancreas, total liver activity represented more than $90 \%$ of total activity.

This result was not reflected either in values of glycine enrichment or in specific radioactivity in the pancreas which were twelve times higher than liver enrichment. It is clear that the high value of pancreas glycine enrichment could be only partly the consequence of the higher level of labelling of the threonine pool. In fact, the absolute value of in vivo threonine oxidation rate depends on glycine flux. On one hand, the value of liver glycine flux estimated by Ballèvre et al. (1991) was high and close to plasma glycine flux. On the other hand, in the pancreas, the part of glycine flux due to protein degradation was probably not as high as expected since, as discussed earlier, pancreatic juice protein is exported, degraded and recycled elsewhere. Moreover, in the pancreas, unlike in the liver, TDG might be the main pathway involved in glycine de novo synthesis. Therefore, the present results may remain consistent with the assumption that the liver was the tissue which oxidized the greatest amount of threonine in vivo when the supply of threonine is not limiting or important, as was the case during the infusion of $100 \mathrm{mg} / \mathrm{kg} \mathrm{BW}$.

\section{The effect of weight and genotype on threonine oxidation}

The comparison of TDG activity and glycine specific radioactivity measured in piglets of different weights (Expt 1, Fig. 1) showed that the changes in TDG specific activity and in glycine specific radioactivity were similar in the pancreas but not in the liver. Consequently, TDG activity was probably not limiting for liver threonine oxidation. This result was consistent with our hypothesis concerning the role of threonine transport as the limiting step for threonine oxidation in the liver but not in the pancreas (Le Floc'h et al. 1996). The lower values of liver and pancreas glycine enrichments measured in $12 \mathrm{~kg}$ pigs could be a consequence of an adaptation to undernutrition associated with weaning which occurred only $10 \mathrm{~d}$ before the infusion.

Our data showed an effect of genotype on pig oxidative capacities. Indeed, TDG specific activity and glycine enrichment measured in liver and pancreas were higher in Large White than in crossbred pigs. These genotypes differ in their growth performance and their ability to use dietary protein and amino acids efficiently for protein deposition. With the same energy and protein intake, crossbred pigs deposited $60 \mathrm{~g} / \mathrm{d}$ more protein than Large White pigs (Quiniou, 1995). Previous results obtained from our laboratory have shown that muscle protein synthesis is $17 \%$ faster in Large White pigs than in crossbred pigs (B. Sève and E. Capparo, unpublished results) probably reflecting higher protein turnover. Consequently, the higher oxidative potential in Large White pigs could be another aspect of a poor metabolic efficiency involving their inability to spare dietary amino acids for protein synthesis. On the other hand, this could signify that Large White pigs were able to clear excess threonine easily. The reason why the difference seemed to affect pancreatic TDG activity more dramatically is unknown. However, previous results have shown that the contribution of the pancreas to total threonine oxidation is more important when dietary threonine supply is low because of the reduced availability of threonine in the liver (Le Floc'h et al. 1996). Therefore, threonine basal oxidation rate, 
representing part of the maintenance requirement, might be higher in Large White than in crossbred pigs.

In conclusion, the present data show that, in pigs, threonine oxidation takes place only in the liver and in the pancreas. The comparison of threonine enrichment in different tissues suggested that threonine was more rapidly taken up in the pancreas than in the liver. This result supports our previous hypothesis that threonine transport might be the limiting step controlling in vivo threonine oxidation in the liver, but not in the pancreas (Le Floc'h et al. 1996). On the other hand, we have shown that Large White pigs would be able to oxidize more threonine than crossbred pigs. This result is consistent with the difference in dietary protein and amino acid efficiency for protein deposition between these two genotypes.

The authors would like to thank Nadine Mézière for GC-MS and P. Ganier for GC-CIRMS analysis, Y. Lebreton and F. Legouëvec for surgical procedure and animal care.

\section{REFERENCES}

Ballèvre, O., Buchan, V., Rees, W. D., Fuller, M. F. \& Garlick, P. J. (1991). Sarcosine kinetics in pigs by infusion of $\left[1-{ }^{14} \mathrm{C}\right]$ sarcosine: use for refining estimates of glycine and threonine kinetics. American Journal of Physiology 260, E662-E668.

Ballèvre, O., Cadenhead, A., Calder, A. G., Rees, W. D., Lobley, G. E., Fuller, M. F. \& Garlick, P. J. (1990). Quantitative partition of threonine oxidation in pigs: effect of dietary threonine. American Journal of Physiology 259, E483-E491.

Bird, M. I., Nunn, P. B. \& Lord, L. A. J. (1984). Formation of glycine and aminoacetone from L-threonine by rat liver mitochondria. Biochimica et Biophysica Acta 802, 229-236.

Corring, T. (1975). Endogenous proteins excreted in the pancreatic juice of swine. Annales de Biologie Animale Biochimie Biophysique 15, 115-118.

Cortamira, N. O., Sève, B., Lebreton, Y. \& Ganier, P. (1991). Effect of dietary tryptophan on muscle, liver and whole-body protein synthesis in weaned pigs: relationship to plasma insulin. British Journal of Nutrition 66, 423-435.

Davis, A. T. \& Austic, R. E. (1982). Threonine degrading enzymes in chicken. Poultry Science 61, $2107-2111$.

Davis, A. T. \& Austic, R. E. (1994). Dietary threonine imbalance alters threonine dehydrogenase activity in isolated hepatic mitochondria of chicks and rats. Journal of Nutrition 124, 1667-1677.

Garlick, P. J., Millward, D. J. \& James, W. P. T. (1973). The diurnal response of muscle and liver protein synthesis in vivo in meal-fed rats. Biochemical Journal 136, 935-945.

Girard-Globa, A., Bourdel, G. \& Lardeux, B. (1980). Regulation of protein synthesis and enzyme accumulation in the rat pancreas by amount and timing of dietary protein. Journal of Nutrition 110, 1380-1390.

Green, M. L. \& Elliott, W. H. (1964). The enzymic formation of aminoacetone from threonine and its further metabolism. Biochemical Journal 92, 537-549.

Hartshome, D. \& Greenberg, D. M. (1964). Studies on liver threonine dehydrogenase. Archives of Biochemistry and Biophysics 105, 173-178.

Husek, P. (1991). Rapid derivatization and gas chromatographic determination of amino acids. Journal of Chromatography 552, 289-299.

Kang-Lee, Y. A. E. \& Harper, A. E. (1978). Threonine metabolism in vivo: effect of threonine intake and prior induction of threonine dehydratase in rats. Journal of Nutrition 108, 163-175.

Le Floc'h, N., Obled, C. \& Sève, B. (1995). In vivo threonine oxidation rate is dependent on threonine dietary supply in growing pigs fed low to adequate levels. Journal of Nutrition 125, 2550-2562.

Le Floc'h, N., Obled, C. \& Sève, B. (1996). In vivo threonine oxidation in growing pigs fed on diets with graded levels of threonine. British Journal of Nutrition 75, 825-837.

Le Floc'h, N., Sève, B. \& Henry, Y. (1994). The addition of glutamic acid or protein to a threonine-deficient diet differentially affects growth performance and threonine dehydrogenase activity in fattening pigs. Journal of Nutrition 124, 1987-1995.

Leterme, P., Théwis, A., Genot, L., François, E. \& Wathelet, B. (1993). Determination of the true ileal digestibility of amino acids in pigs by means of ${ }^{15} \mathrm{~N}$-labelled diets. Prelimingry results. In Nitrogen Flow in Pig Production and Environmental Consequences. EAAP Publication no. 69, pp. $49-54$ [M. W. A. Verstegen, L. A. den Hartog, G. J. M. van Kempen and J. H. M. Metz, editors]. Wageningen: Pudoc Scientific Publishers.

Peng, Y., Gubin, J., Harper, A. E., Vavich, M. G. \& Kemmerer, A. R. (1973). Food intake regulation: amino acid toxicity and changes in rat brain and plasma amino acids. Journal of Nutrition 103, 608-617. 
Ponter, A. A., Cortamira, N. O., Sève, B., Salter, D. N. \& Morgan, L. M. (1994). The effects of energy source and tryptophan on the rate of protein synthesis and on hormones of the entero-insular axis in the piglet. British Journal of Nutrition 71, 661-674.

Quiniou, N. (1995). Effect of growth potential on energy utilisation in pigs: contribution to modelling nutritional requirements and body composition. PhD thesis. Ecole Nationale Supérieure Agronomique de Rennes.

Simon, O., Bergner, H., Münchmeyer, R. \& Zebrowska, T. (1982). Studies on the range of tissue protein synthesis in pigs: the effect of thyroid hormones. British Journal of Nutrition 48, 571-582.

Simon, O., Münchmeyer, R., Bergner, H., Zebrowska, T. \& Buraczewska, L. (1978). Estimation of rate of protein synthesis by constant infusion of labelled amino acids in pigs. British Journal of Nutrition 40, 243252.

Simon, O., Zebrowska, T., Bergner, H. \& Münchmeyer, R. (1983). Investigations on the pancreatic and stomach secretion in pigs by means of continuous infusion of ${ }^{14} \mathrm{C}$-amino acids. Archiv für Tierernährung 33, 9-22.

Statistical Analysis Systems (1989). SAS User's Guide: Statistics. Cary, NC: SAS Institute Inc.

Tressel, T., Thompson, R., Zieske, L. R., Menendez, M. I. T. S. \& Davis, L. (1986). Interaction between Lthreonine dehydrogenase and aminoacetone synthetase and mechanism of aminoacetone production. Journal of Biological Chemistry 261, 16428-16437. 